\title{
The Trend in the Development of Oncolytic Virus Therapy
}

\author{
Sun-II Kwon ${ }^{\dagger ; *}$ \\ Department of Biomedical Laboratory Science, Deagu Health Science University, Daegu 41453, Korea
}

The oncolytic viruses selectively infect and destroy cancer cells, not harming normal cells. The cancer cell materials released by oncolysis, like tumor antigens, stimulate host antitumor immune responses, which is a long-lasting antitumor immunity removing cancer cells in remote parts of the body by a systemic response. Oncolytic viruses armed with transgenes such as cytokines or other immune stimulating factors enhance the immune responses. The first oncolytic virus approved by US-FDA is Imlygic ${ }^{\circledR}$ targeting for melanoma. The oncolytic virus is considered as a revolutionary immunotherapy for tumors together with immune checkpoint inhibitors. A variety of oncolytic viruses are under research in the treatment of kidney cancer, liver cancer, breast cancer, and many others solid tumors. Clinical trials have shown promising results in different types of cancers. Here, we present a brief introduction of various aspects of oncolytic virus, and a review of the current status of oncolytic virus therapy development.

Key Words: Oncolytic virus, Cancer, Virus therapy, Transgenes, Combination therapy

\section{1. 서론}

인간에게 해롭다고 여겨지던 감염성 바이러스가 인간 의 암치료제로 개발되고 있다. 암세포에 선택적으로 침투 하여 암세포를 공격하는 암용해바이러스(oncolytic virus)가 바로 그 것인데, 암용해바이러스 치료법은 이제 유망한 암치료법으로 인식되고 있다. 암용해바이러스는 정상세포 에는 영향을 주지 않고 암세포에서만 선택적으로 복제되 어서 암세포를 죽인다. 암용해바이러스는 유전공학적으로 만들어지거나 자연적인 바이러스가 그대로 사용된다. 유 전자 치료법에서는 바이러스가 단순히 외래 유전자의 전 달체로 사용되지만 암용해바이러스 치료법에서는 암용해 바이러스 자체가 활성 약물이 된다. 암용해바이러스가 암 세포만을 선택적으로 제거하는 특이성을 확보하게 되면서 암용해바이러스는 암정복의 중요한 도구로 부상하게 되었
다. 암용해바이러스는 종양 내에 감염되어 암세포를 직접 죽일 뿐만 아니라 이차적으로 항암면역반응을 유도하여 우리 신체의 면역계가 숨어 있는 암세포를 찾아내어 파 괴하도록 한다. 암용해바이러스는 유효성 또한 좋다. 설 치류 종양모델 실험에서 암용해바이러스는 종양 내에 단 한 번만의 주사로 암을 완치하기도 했다(Naik et al., 2012). 암용해바이러스는 암치료제로서 잠재력이 적지 않다.

서구에서 최초로 허가를 받은 암용해바이러스 치료제는 임리직(Imlygic, T-Vec, talimogene laherparepvec)인데, 흑색종 치료제로 2015년 미국에서, 2016년 유럽에서 각각 판매승 인을 받았다(Greig, 2016). 임리직은 병원성이 없도록 유전 적으로 조작한 헤르페스 바이러스(herpes simplex virus)에 granulocyte-macrophage colony stimulating factor (GM-CSF) 유전자를 삽입한 것이다. 임리직을 암세포 부위에 국소 주 사하면 이 재조합 바이러스는 암세포 내에서 증식하게 되 는데, 충분히 증식하고 나면 암세포를 파열시키면서 밖으

Received: July 5, 2019 / Revised: September 10, 2019 / Accepted: September 11, 2019

*Professor.

${ }^{\dagger}$ Corresponding author: Sun-Il Kwon. Department of Biomedical Laboratory Science, Deagu Health Science University, Youngsong-ro 15 (Taejeon-dong), Buk-ku, Daegu 41453, Korea.

Tel: +82-53-320-1302, Fax: +82-53-320-1450, e-mail: psikwon@dhc.ac.kr

(C) The Korean Society for Biomedical Laboratory Sciences. All rights reserved.

@ This is an Open Access article distributed under the terms of the Creative Commons Attribution Non-Commercial License (http://creativecommons.org/licenses/by-nc/3.0/) which permits unrestricted non-commercial use, distribution, and reproduction in any medium, provided the original work is properly cited. 
로 나온다. 이때 바이러스가 생성한 면역반응을 유도하는 GM-CSF가 동시에 방출되어 수지상세포와 결합한다. 이 후 수지상세포는 종양으로 발생한 암세포를 인식하여 면 역세포에게 정보를 전달하고, 순차적으로 면역계는 스스 로 종양세포를 공격하게 된다. 임리직은 2주 간격의 종양 내 국소 투여로 주사 부위에서 $47 \%$ 의 완전관해를 이루었 고, 동시에 전신 면역반응으로 원거리 비감염암에서 $9 \%$ 의 완전관해를 이루었다(Andtbacka et al., 2016). 다른 면역 관문억제제와 병용 투여를 한 시험에서는 더욱 향상된 효 과를 보여주었다(Puzanov et al., 2016; Maroun et al., 2017).

현재 세계적으로 다수의 암용해바이러스 치료제 후보 가 종양모델 실험동물과 인간을 대상으로 임상시험이 진 행되고 있어서, 앞으로 새로운 암용해바이러스 치료제가 등장할 것으로 예상된다(Lundstrom, 2018). 본 연구는 종양 의 치료에서 암용해바이러스의 중요성이 커져 감에 따라 암용해바이러스 치료제와 관련된 연구 개발의 흐름을 조 망해 보고자 한다.

\section{2. 암용해바이러스 치료제 개발의 역사적인 과정}

\section{2-1. 항암치료제 개발의 역사}

전통적으로 사용되어 온 화학항암제를 제 1 세대 항암제 라고 하는데, 세포독성 항암제로서 정상세포보다 빠르게 자라는 암세포를 선택적으로 죽이는 방법이다. 암세포는 정상세포에 비하여 분열이 왕성하여 세포주기가 빠른데, 세포주기 중 DNA 합성시기의 세포를 선택적으로 제거하 여 암의 성장을 억제한다.

암세포에 대한 선택성을 높여 부작용을 줄인 항암제를 2세대 항암제라고 한다. 이들은 암세포에 특이적으로 존 재하는 분자생물학적인 표적을 이용하기 때문에 표적치료 제라고 부른다. 표적치료제는 암세포에서 차별적으로 과 다 발현되는 특정 단백질이나 특정 유전자의 변화를 표적 으로 삼아서 암의 성장과 발생에 관여하는 신호를 차단함 으로써 암세포를 죽인다.

우리 몸의 면역체계를 활성화시켜서 면역세포가 암세포 를 제거하게 하는 면역항암제를 3세대 항암제라고 부른다. 면역항암제는 우리 자신의 면역세포를 이용하여 선택적으 로 암세포를 공격하게 만드는데, 면역세포가 암세포를 특 이적으로 인식하여 스스로 치료하도록 돕는 방식이다. 제 3세대 면역치료제로는 암용해바이러스(oncolytic virus), 면 역관문억제제(immune check point inhibitor), CAR-T (chimeric antigen receptor T cells) 치료제 등이 포함된다(Kwon, 2017).

최근 10 여년 동안 항암제의 개발은 주로 인간의 면역반 응에 기반을 둔 면역항암치료제가 주류를 이루고 있다. 면역항암제는 표적치료제와 더불어 암치료 방법의 흐름 을 바꾸고 있다. 암용해바이러스는 항암면역기능 활성화 측면에서도 주목을 받고 있다(Bommareddy et al., 2018).

\section{2-2. 암용해바이러스 치료제 개발 과정}

암용해바이러스 치료법의 개념은 상당히 오랜 기간 존 재해왔다. 이미 오래 전부터 사람들은 심한 독감을 않거 나 다른 감염질환을 않은 후에 가끔 백혈병이 감쪽같이 사라졌다거나 다른 종양이 현저히 위축되었다는 사실을 경험적으로 알았다. 바이러스의 전신성 감염 후에 종양이 줄어드는 현상은 여러 군데서 자주 관찰되었다(Smith et al., 1956). 암용해바이러스 치료제 개발은 이러한 관찰에서 비 롯된다. 1949년 22명의 호지킨병 환자가 간염 바이러스를 함유하는 혈청이나 조직 추출물로 치료를 받았다(Hoster et al., 1949). 1950년부터 1980년까지 보다 안전하고 효과적 인 결과를 얻기 위하여 수많은 노력이 경주되었으나 별다 른 임상적 성과가 없이 막을 내렸다. 이는 주로 바이러스 의 독성을 조절하거나 종양 특이성을 확보하는 방법이 그 때까지 미비하여 바이러스 처치 방법이 안전하지 않았기 때문이었다. 그러나 1980년대에 들어서 유전공학이 발달 하면서 암용해바이러스 치료법에 대한 관심이 다시 부상 하였고, 그 후 30 여년간 괄목할 만한 진전이 이루어졌다 (Howells et al., 2017).

1950년부터 1990년까지는 야생형 바이러스나 약독화된 바이러스로 암치료를 시도하였다. 주로 사용된 바이러스 는 간염 바이러스, 웨스트나일열병 바이러스, 황열병 바 이러스, 뎅기열병 바이러스 등이었는데 치료제로서 효용 가치는 낮았다.

대부분의 암세포는 바이러스 감염에 대한 방어 기전(예 를 들면, 베타-인터페론 신호전달경로)이 손상되어 있어 서, 바이러스는 정상세포보다 암세포에서 훨씬 잘 복제된 다. 그러므로 암세포에서 바이러스를 복제시키는 일은 비 교적 쉬운 일이다. 정작 어려운 문제는 바이러스가 암세 포에서는 복제가 잘 되면서 정상세포에서는 복제가 되지 않게 하는 것이다. 암세포 특이적인 복제를 이루기 위하 여 인간에게 병원성이 없는 바이러스를 선별하거나, 바이 러스 게놈을 유전공학적으로 조작하면 된다. 병원성이 없 는 바이러스의 예는 레올리신(Reolysin)인데, 레오바이러 스(Reovirus)의 야생형 변이주로 Ras 신호전달경로가 활성 
화된 암세포에서는 암살상(oncolytic) 특성을 가진 반면 정 상세포에서는 병원성이 거의 없다. 바이러스 게놈을 조작 할 때에는 바이러스 복제를 엄격하게 통제하는 전략을 쓴 다. 유전공학적으로 thymidine kinase에 돌연변이를 일으킨 Herpes simplex virus type I (HSV-1)는 암세포에서만 특이적 으로 복제를 하며, 뇌종양의 치료에도 유용한 것으로 밝 혀졌다(Martuza et al., 1991). 이 고무적인 연구 결과는 암용 해바이러스 치료제 개발에 바이러스 게놈 디자인을 적극 적으로 도입하게 하였다. 암용해바이러스 치료제 개발과 관련하여 가장 중요한 발견은 '암용해 과정 중에 전신적인 종양 특이면역(systemic tumor-specific immunity)이 효과적으 로 유도된다'는 점이다. 이 현상은 모든 암용해바이러스 치료에서 암환자의 생존을 연장시키는 중요한 특징으로 인식되고 있다(Fukuhara et al., 2016).

유전공학적으로 조작된 암용해바이러스 치료제로 온코 린(Oncorine $\left.{ }^{\mathrm{TM}}\right)$ 과 임리직(Imlygic $\left.{ }^{\mathrm{TM}}\right)$ 이 있다. 온코린은 두경 부암과 식도암치료제로 2005년에 중국에서 판매가 승인 되었다(Garber, 2006). 세포는 바이러스에 감염되면 p53 단 백질의 중재에 의해 세포주기를 늦추고 세포자멸사(apoptosis)를 일으켜서 바이러스의 증식을 막는다. 아데노바이 러스의 E1B 유전자 산물은 숙주의 p53 유전자 산물에 결 합하여 이를 불활성화 시킴으로써, 숙주세포가 바이러스 복제를 억제하는 것을 방해한다. 온코린은 아데노바이러 스에서 $\mathrm{E} 1 \mathrm{~B}$ 산물의 유전자를 제거한 것이다. 따라서 $\mathrm{E} 1 \mathrm{~B}$ 산물의 발현이 결여된 온코린은 p53 산물이 없는 암세포 (대부분의 암세포는 돌연변이에 의해 p53 산물이 없다)를 만나면 복제능력을 유지하는 반면, 정상적으로 $\mathrm{p} 53$ 산물 을 생산하는 정상세포를 만나면 p53 산물에 의하여 바이 러스의 복제능력에 제약을 받게 된다(Vollmer et al., 1999). 온코린은 치료제로서 더 이상 확장되지 못하고 그 사용 이 아직까지 중국 내에 국한되어 있다.

임리직은 유전공학적으로 조작된 herpes simplex virus-1 (HSV-1)이다. 두 개의 유전자 $(\gamma-34.5$ 및 $\alpha-47)$ 가 제거되어 있고 인간의 GM-CSF (Granulocyte-macrophage colonystimulating factor, 과립구 대식세포 콜로니 자극 인자) 유전 자가 제거된 부위에 추가되어 있다. 임리직은 암세포에서 증식하여 암세포를 터트리고, 면역반응을 자극하여 암세 포를 다시 공격하도록 설계되었다(Hu et al., 2006; Fukuhara et al., 2016).

\section{3. 암용해바이러스 특성과 대표적인 치료제}

\section{3-1. 암용해바이러스 치료제의 일반적인 특성}

일반적으로 암용해바이러스를 설계할 때는 여러 가지를 요소를 고려해야 하지만 최소한 5 가지 조건에는 부합하 여야 한다. 이 5 가지 조건으로는 표적 종양에 대한 특이 성을 가지고, 감염된 종양세포를 죽이는 파괴력을 가지며, 항종양면역을 유도하는 능력을 보유하고, 부작용을 최소 화하고, 바이러스가 가지는 본연의 감염력이 복원하지 못 하도록 해야 하는 것이다(Maroun et al., 2017).

암용해바이러스는 암을 용해하여 암을 치료하는 표적 바이러스 치료(targeted oncolytic virotherapy) 방법이다. 화학 적 혹은 항체 표적항암제처럼 암용해바이러스는 정상세 포와 구분이 되는 종양세포 내의 비정상적인 부위를 표 적으로 삼는다. 암용해바이러스는 암세포에서 활성화된 유전대사경로나, 암세포에서 소실된 종양억제인자기능을 표적으로 삼아 종양세포를 선택한다. 암용해바이러스는 종괴 내에서 선택적으로 복제되어 암세포를 용해한다. 복 제된 딸 바이러스는 인접 조직을 통해 확산되어 먼 곳에 있는 종양세포도 순차적으로 죽인다(Fig. 1) (Davola and Mossman, 2019).

암용해바이러스에는 유전자 조작을 통해 여러 가지 치 료 목적의 유전자(transgene)가 삽입되어 있다. 이 유전자 들이 발현되어 종양 특이적 세포독성 $\mathrm{T}$-림프구를 유도하 거나, 종양세포를 직접 사멸시킨다. 예를 들면 GM-CSF와 같은 사이토카인 유전자를 발현시켜서 종양세포에 대한 면역반응을 증강시키거나, 전구약물(pro-drug) 전환효소 유 전자가 그 산물로써 주변 종양세포를 죽인다. 암용해바이 러스에 신생혈관억제 관련 유전자를 도입하여 종양혈관을 차단을 하여 종양을 괴사시키기도 한다(Woo and $\mathrm{Hu}, 2015)$. 종양세포가 용해될 때는 종양관련항원(tumor-associated antigen)과 같은 면역유발물질이 분비되어 항종양면역반응 이 유도된다(Fig. 1) (Davola and Mossman, 2019).

바이러스가 세포를 감염시킬 때는 정상세포는 피하고 종양세포만 표적으로 삼아 침투시키는 것이 좋은데, 그 침 투 기전에는 여러 가지가 있다. 백시니아 바이러스는 수 용체를 통하는 대신 내포작용으로 세포에 들어간다. 아데 노바이러스는 아데노바이러스 수용체나 인테그린, CD46 에 결합하며 숙주세포로 들어가고, 헤르페스바이러스는 헤르페스바이러스 입장중재자(entry mediator)와 결합하여 들어간다. 


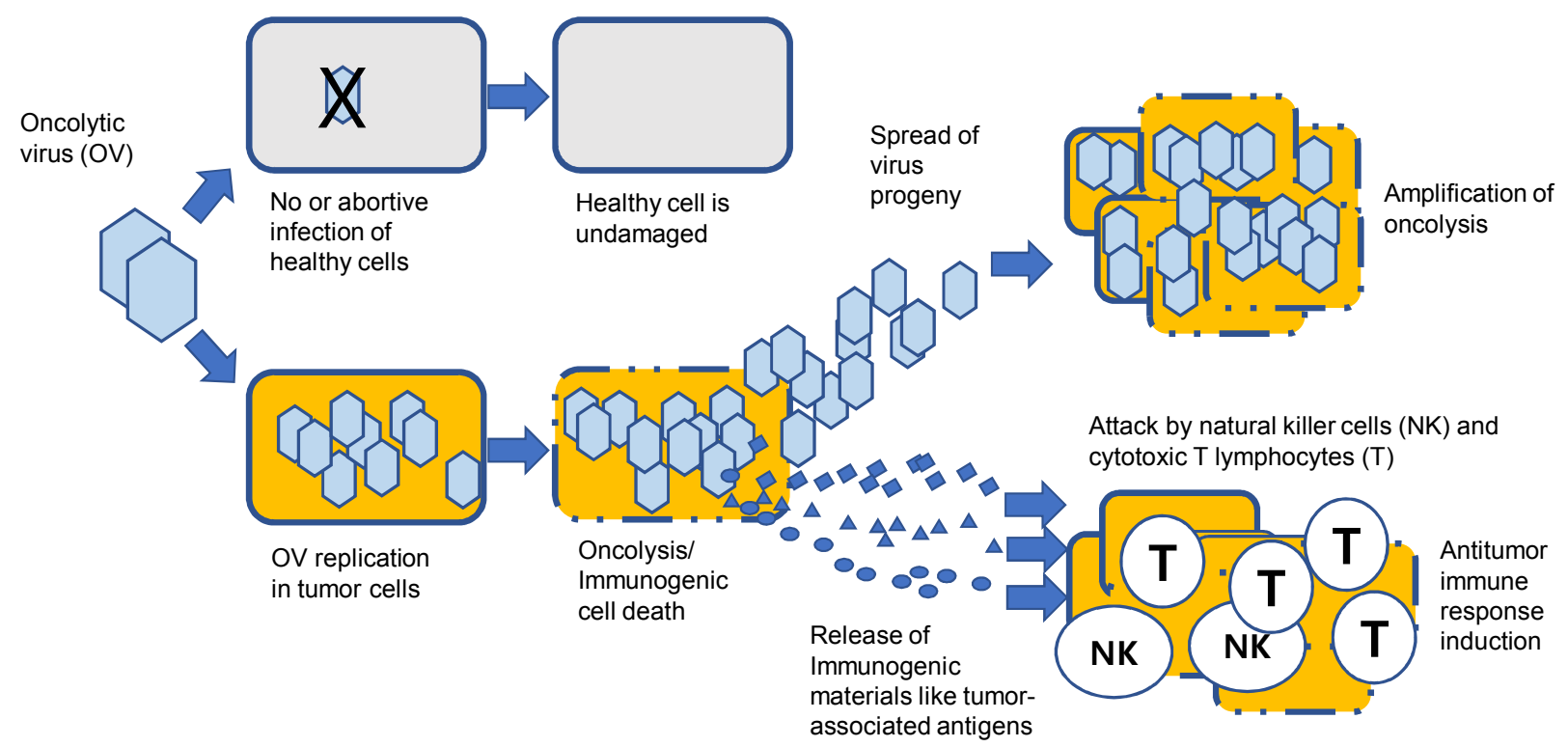

Fig. 1. Action mechanism of oncolytic virus $(\mathrm{OV})$. OVs destroy selectively cancer cells while having minimal effect on healthy cells. OVs attack tumor cells by two different mechanisms; direct tumor cell lysis and indirect augmentation of host immune activity (Davola and Mossman, 2019).

\section{3-2. 대표적인 암용해바이러스 치료제}

암용해바이러스 치료제 용으로 다양한 종류의 바이러스 가 세계적으로 연구되고 있다.

현재 임상시험이 진행되고 있는 바이러스로는 Herpes simplex virus, Adenovirus, Measles virus, Vaccinia virus, Reovirus, Coxsackievirus, Parvovirus, Poliovirus, Rhinovirus 등이 있다(Table 1, Raja et al., 2018). 서구에서 유일하게 판매가 이루어진 임리직과 판매승인에 근접한 것으로 여겨지는 펙사벡과 레올리신을 대표적인 예로 살펴보고자 한다.

\section{3-2-1. 유전자 조작 암용해바이러스 임리직(T-vec)}

임리직은 herpes simplex virus-1 (HSV-1)를 조작하여 디자 인한 것인데, $\gamma-34.5$ 유전자와 $\alpha-47$ 유전자를 결실시켰으 며, transgene으로서 human granulocyte macrophage colonystimulating factor (GM-CSF)를 $\gamma-34.5$ 결실 부위에 삽입하 였다.

정상적인 숙주세포는 바이러스에 감염되면 단백질합성 을 차단(shut-off)하여 바이러스의 증식을 막아 자신을 방 어한다. HSV-1에 내재된 $\gamma-34.5$ 유전자의 역할은 감염 후 숙주세포의 단백질합성 차단작용을 무효화시켜서 자기 복 제를 원활하게 하는 것이다. HSV-1에 $\gamma-34.5$ 를 불활성화시 키면 정상세포에서는 숙주세포의 단백질합성 차단작용으
로 바이러스의 복제가 어려워진다. 대부분의 암세포에는 단백질합성 차단반응이 없다. 따라서 $\gamma-34.5$ 유전자가 결 손된 HSV-1(임리직)은 정상세포에서는 복제가 어려운 반 면 암세포에서는 잘 증식하게 된다. 즉 $\gamma-34.5$ 유전자 결 손은 바이러스에게 종양세포에 선택적인 복제능력을 부여 한다.

$\alpha 47$ 유전자는 항원제시와 관련된 수송체(transporter)에 길항하여 그 작용을 억제한다. $\alpha 47$ 이 결실된 바이러스는 감염된 암세포에서 $\mathrm{MHC}$ class I의 발현을 증가시키게 된 다. 감염된 종양세포의 $\mathrm{MHC}$ class I 발현 증가는 결과적으 로 종양 면역반응 유도를 강화시킨다. $\alpha 47$ 결실은 또한 인근 US11 유전자의 즉각적인 조기 발현을 일으키는데, 이는 암세포에서 바이러스의 복제를 증가시킨다.

GM-CSF는 항종양면역의 유도를 강화하기 위하여 삽 입되었는데, 인간의 GM-CSF 유전자 두 개가 $\gamma-34.5$ 결실 부위에 위치한다. GM-CSF는 조절 사이토카인으로서 염 증 부위에서 수지상세포의 축적을 자극하고, 항원제시세 포의 기능을 촉진하고, T-세포 반응을 촉발한다. 암용해바 이러스 유전체에 GM-CSF를 넣은 경우 동물실험에서 종 양의 감소와 전체 생존율의 유의한 증가가 관찰되었다 (Agarwalla and Aghi, 2012; Kohlhapp and Kaufman, 2016).

임리직은 유방암, 두경부암, 위장관계암, 악성흑색종 환 자를 대상으로 한 안전성 시험에서 종양 내 투여 시 모든 
Table 1. Current and recently completed trial I and II using oncolytic viruses (Raja et al., 2018)

\begin{tabular}{|c|c|c|}
\hline Virus & Strain & Targeted malignancy \\
\hline \multirow[t]{4}{*}{ Herpes simplex virus I } & Talimogene Laherparepvec (T-Vec) & Breast, Melanoma and pancreatic \\
\hline & TBI-1401 (HF10) & Superficial solid tumors and melanoma \\
\hline & G207 & Glioma \\
\hline & HSV1716 & Mesothelioma, Bone, Sarcomas and neuroblastomas \\
\hline Adenovirus/Herpes & ADV/HSV-tk & Breast and NSCLC \\
\hline \multicolumn{3}{|l|}{ Simplex virus } \\
\hline \multirow[t]{11}{*}{ Adenovirus } & LOAd703 & PancreaticNSCLC \\
\hline & CG0070 & Bladder \\
\hline & ColoAd1 (Enadenotucirev) & Colorectal, NSCLC, Bladder, Epithelial \\
\hline & & Renal cell and ovarian \\
\hline & ONCOS-102 & Advanced solid tumors and melanoma \\
\hline & DNX-2401 & Brain \\
\hline & VCN-01 & Advanced solid tumors and pancreatic \\
\hline & Ad-MAGEA3 and MG1-MAGEA3 & NSCLC and advanced solid tumors \\
\hline & NSC-CRAd-Survivin-pk7 & Glioma \\
\hline & Ad5-yCD/mutTKSR39rep-hIL12 & Prostate \\
\hline & Ad5-yCD/mutTKSR39rep-ADP & NSCLC \\
\hline Measles & MV-NIS & $\begin{array}{l}\text { Breast, Head and neck, Ovarian, Nerve sheath, Mesothelioma } \\
\text { and multiple myeloma }\end{array}$ \\
\hline \multirow[t]{2}{*}{ Vaccinia } & GL-ONC1 & Advanced solid tumors, Head and neck and ovarian \\
\hline & $\begin{array}{l}\text { Pexastimogene devacirepvec } \\
\text { (Pexa-Vec) }\end{array}$ & $\begin{array}{l}\text { Hepatocellular, Head and neck, Colorectal, Advanced solid } \\
\text { tumors, Blue cell, Melanoma, Lung and renal cell }\end{array}$ \\
\hline Reovirus & REOLYSIN & $\begin{array}{l}\text { Colorectal, Bladder, Pancreatic, Multiple myeloma, Plasma } \\
\text { cell cytoma, Ovarian and peritoneal }\end{array}$ \\
\hline Coxsackievirus & CVA21 (CAVATAK) & Melanoma and NSCLC \\
\hline Parvovirus & H-1PV (ParvOryx) & Glioblastoma multiforme \\
\hline Polio/Rhinovirus & PVSRIPO & Glioma \\
\hline
\end{tabular}

환자에 게서 잘 관용되었다(Hu et al., 2006; Fukuhara et al., 2016).

\section{3-2-2. 유전자 조작 암용해바이러스 펙사벡(Pexa-Vec,} pexastimogene devacirepvec, JX-594)

펙사벡은 유전공학적으로 조작된 백시니아 바이러스 (vaccinia virus)이다. 벡시니아 바이러스는 자연적으로 정 상세포보다 암세포에서 더 잘 증식하는 고유의 종양친화 성을 가지고 있다. 암세포 주변의 신생혈관은 새기가 쉬 워 벡시니아 바이러스의 침투가 용이하다. 또한 암세포는 증식률이 높아서 바이러스 복제에 필요한 뉴클레오시드 풀을 만들어 벡시니아 바이러스에게 복제하기 좋은 환경 을 제공한다.
펙사벡의 백시니아 바이러스는 티미딘인산화효소(thymidine kinase)가 돌연변이로 불활성화 되어 있다. 암세포는 활발한 복제로 인하여 티미딘인산화효소가 충분히 발현되 어 분비된다. 티미딘인산화효소를 만들지 못하는 펙사벡 은 암세포에서는 이 효소를 이용하여 증식할 수 있다. 그 러나 정상적인 숙주세포에서는 티미딘인산화효소가 부족 하므로 펙사벡은 증식이 어렵다. 펙사벡은 암세포만을 선 택적으로 공격하여 파괴하는데, 이 과정에서 분출된 암세 포 특이 물질들이 체내 면역반응을 연쇄적으로 촉진시켜 암세포를 공격한다. 펙사벡에는 인간 GM-CSF 유전자도 삽입되어 있다. GM-CSF 산물은 종양 특이 항종양면역반 응을 자극한다. 펙사벡에는 $\mathrm{Lac}-\mathrm{Z}$ 유전자가 마커로 삽입 되었다(Parato et al., 2012). 
백시니아 바이러스 사용의 장점은 정맥 투여에서 안정 적이고, 세포독성이 강하며, 생백신으로서 안전성이 우수 하다는 점이다. 펙사벡은 현재 간세포암종(hepatocellular carcinoma)에 대하여 단독 혹은 병용으로 임상2상과 3 상 시험이 진행 중이다(Fukuhara et al., 2016; Yamada et al., 2018; Guo et al., 2019). 펙사벡은 한국의 '신라젠'사에서 개발을 주도하고 있다.

\section{3-2-3. 자연적인 암용해바이러스 레올리신(Reolysin)}

보통 암치료에 사용되는 바이러스는 사람에게 병원성 이 없도록 유전자를 조작한 것이다. 그러나 Reovirus의 경 우에는 조작이 없이 자연적인 상태의 바이러스를 그대로 치료에 사용한다. Reovirus는 이중가닥 RNA 바이러스인 데 정상세포보다 종양세포에서 복제가 잘된다. Reovirus의 암용해 특성은 Ras 신호전달 활성에 의존한다. 레올리신 (Reolysin)은 Reovirus의 T3D strain인데 항암제로서 많이 연구되었으며 현재 자연적인 바이러스 상태로 임상연구에 사용되고 있다(Gong et al., 2016). 전이 고형암, 흑색종, 두 경부암 등의 증상에 대하여 임상2상 시험이 완료되었으 며, 두경부암에 대해서는 임상 3 상 연구가 진행되고 있고, 전이성 유방암, 폐암, 췌장암에도 임상시험이 진행되고 있다(Fukuhara et al., 2016; Eissa et al., 2018). 레올리신은 캐 나다 캘거리 소재의 생명공학기업 온콜리틱스 바이오테크 (Oncolytics Biotech)에서 개발하고 있다.

\section{4. 암용해바이러스의 항암효과 증진 방법}

\section{4-1. 암세포 선택적인 감염 및 직접적인 암세포 용해 (direct cancer cell lysis)}

바이러스가 암세포에만 감염되어 복제와 증식이 되는 선택성은 암용해바이러스에서 가장 중요한 요소이다. Reovirus나 New Castle virus 등은 자연적으로 종양세포를 선 택적으로 감염시키는 특징이 있다. p53 유전자의 불활성 화나 세포사멸 저하 등 암세포 특유의 변화가 이들 바이 러스의 복제 과정에 유리하게 작용하여 생기는 현상이다. 다른 바이러스의 경우에는 변형과 조작을 통하여 종양세 포에 선택적 감염을 유도한다(Cho et al., 2013). 각 바이러 스는 종양세포를 특이적으로 표적화하기 위하여 여러 가 지 원리를 사용한다. 바이러스에 따라 miRNA 표적, 인터 페론 결함, Ras signaling, thymidine kinase 결실 등의 도구 를 사용하여, 암용해바이러스가 암세포에 특이적으로 감 염되도록 한다. Thymidine kinase가 결실된 바이러스의 경
우에는 핵산의 합성이 왕성한 암세포에서만 선택적으로 자기자신을 복제하여 많은 비리온을 생성한 후 암세포를 용해시킨다. 용해된 암세포에서 방출된 비리온은 주변의 암세포에 순차적으로 감염되어 다시 암용해 작용을 일으 킨다.

용해된 암세포에 의해 노출된 암세포 물질들은 항원제 시세포에 의하여 포획된 다음 종양 특이적인 $\mathrm{T}$-세포 반 응을 유발시킨다. 전신적인 T-세포 반응으로 인하여 멀리 위치한 같은 종류의 종양도 발견하여 2차적으로 공격하 게 된다.

\section{4-2. 면역 증강 기능(enhancing immunogenicity) 부여}

암용해바이러스는 직접 암세포를 사멸시키는 작용을 하 지만 이에 더하여 $\mathrm{NK}$ 세포와 $\mathrm{T}$ 세포로 인한 면역활성화 를 유도하여 항암능력을 증강시킨다. 암용해바이러스를 만들 때는 면역기능을 증진시키는 유전자를 암용해바이러 스 벡터에 삽입하여 무장시킨다. 면역력 증진을 위한 무 장(arming)으로 GM-CSF, interleukin (IL)-2, IL-4, IL-10, IL-15, interferon (INF)- $\alpha, \mathrm{INF}-\beta, \mathrm{INF}-\gamma$ 등의 유전자가 사용된다. 이 삽입 유전자가 생성하는 물질들은 세포독성 면역세포 (cytotoxic immune effector cells)들이 작동하여 2차적으로 나머지 암세포를 제거하도록 한다(Kim, 2017).

\section{4-3. 종양 특이적 억제 유전자의 삽입(insertion of tumor suppressor genes)}

종양의 성장에는 혈관신생이 필요하다. 혈액을 통하여 산소와 영양분이 공급되지 않으면 암세포는 사멸한다. 암 세포에 혈액공급을 차단하기 위하여 혈관신생을 억제하는 유전자나 억제물질 관련 유전자를 암용해바이러스에 삽 입한다. Vascular endothelial growth factor (VEGF), endostatin, angiostatin, vasculostatin, fibroblast growth factor receptor 등 과 관련된 유전자나 microRNA를 삽입하기도 한다(Kim, 2017). 바이러스를 사용하기 위해서는 바이러스의 생활사 를 잘 이해하고, 접종 가능한 최대 바이러스 농도를 알아 야 하며, 바이러스를 제거하기 위한 항바이러스제의 존재 도 확보되어야 한다. 유전자의 조작도 용이하여야 하며, 인체 투여 시 발생하는 면역원성, 야생형 바이러스의 병 원성도 고려하여야 한다(Kim, 2017; Maroun et al., 2017).

\section{4-4. 암용해바이러스의 제한}

암용해바이러스는 야생형 모체 바이러스의 특성을 가 지고 있는데 이것이 장점이나 단점으로 작용한다. HSV-1 
에서 유래한 T-vec(임리직)의 경우 세포간 확산 시 바이 러스 혈증을 일으키지 않는다. 따라서 T-vec은 병변 내부 (intralesional)에만 투여하며 정맥 주사용으로는 사용하지 않는다. T-vec의 국지적인 병변 내부 투여가 전신적인 항 종양면역을 유도하여 원거리 병소에서도 효과가 나타났 다. 이 전신적인 항종양면역반응은 HSV-1 바이러스 자 체의 항종양면역 유도 특성에 기인한 것으로 여겨진다 (Varghese et al., 2006).

암용해바이러스 치료에서 중요한 관심은 치료효과가 순환항체에 의해서 감소될 수 있다는 점이다. 바이러스 혈 증을 일으키는 바이러스는 중화항체의 공격을 당하기 쉽 다. 정맥 투여한 바이러스는 이전에 치료를 받았거나 백 신을 투여 받은 환자에게는 항종양효과가 제한적일 수 있다. 순환항체에 의한 효과 감소는 암용해바이러스를 정 맥 투여한 홍역을 않았던 환자에게서 관찰되었다(Russell et al., 2014). 순환항체에 의한 방해를 극복하기 위해서 reovirus로 동물실험을 해본 결과, 전신적인 치료를 위해 서는 reovirus를, 혈청 내에서 중화항체 수준이 올라가기 전에, 첫 주 내에 빠르게 반복하여 고용량으로 투여하는 것이 바람직하였다(Gong et al., 2016).

암용해바이러스를 반복하여 투여하면 바이러스에 대한 면역이 생겨서 치료를 지속하기 힘들다. 면역기능이 많이 약화된 말기암의 경우 암용해바이러스를 투여해도 되는지 아직 검증이 불충분하다. 또한 암용해바이러스를 투여해 도 모든 암세포가 사멸하는 것은 아니다. 암세포는 다양 한 돌연변이를 하므로 암용해바이러스 치료에도 살아남 는 암세포가 남아 있을 수 있다.

\section{5. 암용해바이러스의 국내외 개발 현황}

\section{5-1. 암용해바이러스의 세계적인 임상시험 현황}

ClinicalTrials.gov(미국 NIH, US National Library of Medicine 산하 기구, https://www.clinicaltrials.gov/)는 전세계에 서 수행되고 있는 임상시험을 총망라하여 database를 구 축하고 있다. 단어 'oncolytic'을 키워드로 검색해본 결과 2019년 6월 23일 현재 97건의 암용해바이러스 임상시험 이 진행되고 있는 것으로 나타났다. 임상 1 상 초기가 1건, 임상1상이 69건, 임상2상이 37건, 임상3상이 5건, phase not applicable이 2건으로 나타났다. 다른 phase의 임상시험이 동시에 진행되고 있는 경우가 있어서 개별 건수의 합이 총건수를 상회하는 것으로 추정된다.

임상시험의 적응증으로는 방광암, 뇌암, 두경부암, 신장
암, 간암, 흑색종, 췌장암, 전립선암 등이 있다. 사용되는 바이러스로는 헤르페스바이러스, 아데노바이러스, 홍역바 이러스, 백시니아바이러스, 레오바이러스, 소아마비바이 러스, 콕사키바이러스, 파르보바이러스, 레트로바이러스 등이 있다. 레오바이러스, 콕사키바이러스, 파르보바이러 스의 경우에는 야생형 바이러스를 그대로 사용하고, 소아 마비바이러스의 경우 약독화된 바이러스를 사용하였다. 다른 바이러스들은 바이러스에 따라 thymidine kinase 결실, GM-CSF 삽입 등의 다양한 유전적인 조작을 가하여 사용 하였다(Lawler et al., 2017; Lundstrom, 2018; Bommareddy et al., 2018).

\section{5-2. 암용해바이러스의 국내 개발 현황}

국내에서도 여러 업체가 암용해바이러스 치료제를 개 발하고 있다. 앞에서 언급한 것처럼 펙사벡은 우리나라의 신라젠에서 개발하고 있다. 펙사벡은 우두바이러스를 이 용한 간암치료제이다. ClinicalTrials.gov에 의하면 펙사벡은 2019년 6월 현재 임상1상 시험 10건, 임상2상 시험 9건, 임상 3 상 시험이 1 건이 진행 중이다. 펙사벡은 면역관문억 제제인 옵티보와 같은 다른 치료제와의 병용 투여 임상시 험도 진행 중이다. 시험 중인 적응증으로는 대장암·위암 · 담도암·췌장암·기타 고형암의 간 전이 및 면역관문억 제제 내성 고형암 등이다. 신라젠은 독립적 데이터 모니 터링위원회(Independent Data Monitoring Commitee, DMC) 의 임상중단 권고를 받아서 펙사벡의 간암 환자를 대상 으로 한 임상3상을 조기에 종료한다고 2019년 8월 4일 발표하였다. 그러나 다른 적응증의 병용 투여 임상시험은 계속 진행한다고 한다.

코오롱생명과학은 폭스바이러스를 이용한 암용해바이 러스 물질인 KLS-3020의 동물실험을 진행 중이며, 2019년 중 임상1상 시험에 진입할 예정이다. KLS-3020은 암 동물 모델에 1 회 투여만으로도 암의 성장이 현저히 감소됨이 확인된 바 있다. 동사는 종양살상 바이러스 치료효능을 증가시킬 수 있는 폭스바이러스 프로모터에 대한 특허를 취득했다고 2019년 6월 15일 밝혔다.

헬릭스미스는 자사에서 분리한 야생형 레오바이러스를 위암치료에 적용시키는 연구를 하고 있다. 레오바이러스 는 호흡기, 장관에 존재하는 무해한 바이러스인데, 야생형 혹은 약독화된 레오바이러스를 그대로 사용해 암치료에 사용한다. 레오바이러스는 정상세포에는 감염이 잘 일어 나지 않는 반면 암세포에는 특이적으로 감염이 일어날 수 있어서 암세포를 효과적으로 사멸시킬 수 있다. 캐나다의 
레올리신은 미국 소아에게서 분리된 레오바이러스 혈청 3형 데어링(Reovirus type 3 Dearing)인 반면, 헬릭스미스의 레오바이러스는 한국의 소아에게서 독자적으로 분리한 것 이다.

진메디신은 한양대학교 학내 벤처회사로 출발하여 암 용해바이러스를 개발하고 있다. 종양세포에 특이적인 암 용해 아데노바이러스를 연구하고 있는데, 이 회사는 다양 한 암용해 아데노바이러스를 개발하기 위한 기초적인 플 랫폼을 구축하고 있다. 종양 특이성을 높이기 위한 치료 유전자 삽입 등의 유전자 조작을 하고, 사이토카인을 발 현시키고, 면역 억제적인 종양의 미세환경을 극복하기 위 한 면역치료방법을 탐색하고, 인체 중화항체와 싸우기 위 한 나노파티클 바이러스 입자를 개발하는 등의 연구를 하고 있다. 진메디신은 프로모터를 개량하고 치료 유전자 를 동시에 여러 개를 삽입하여 치료효율을 높이는 시도 도 한다. 바이러스를 코팅하여 전신 투여용 바이러스 기 술도 확보했다. 코팅으로 몸속 면역세포들이 바이러스를 독소로 인식하지 못하게 위장하여 혈액 투여 시 생존율을 높였다. 다른 항암바이러스에 비해 간독성도 낮추었다고 한다. 전신 투여용 항암바이러스 치료제는 암치료 방식에 진전을 가져올 것으로 기대된다.

이외에도 다수의 바이오 벤처회사들이 암용해바이러스 연구 개발에 진입하고 있다.

\section{6. 결론 및 논의}

암치료의 방식이 바뀌고 있다. 2 세대 표적치료제와 3 세 대 면역항암제의 등장으로 암치료의 도구가 다양해지면 서 이 무기들을 따로 혹은 같이 섞어서 사용하여 치료효 과를 높이는 방법이 시도되고 있다. 제 $1,2,3$ 세대 함암 제를 적절히 같이 투여하는 병용치료법으로 치료효과가 증진된 사례가 많이 보고되었다. 암용해바이러스도 다른 표적치료제 혹은 면역관문억제제나 CAR-T 세포 등의 다 른 면역항암제와 병용 투여하여 시너지를 높이는 임상시 험을 하고 있다. 암용해바이러스인 펙사벡의 경우 고형암 과 유방암, 연조직 육종을 대상으로 옵티보, 여보이 등의 다른 면역항암제와 병용 투여에서 치료효과가 증진된다는 결과가 나왔다. 면역치료법을 병용할 때는 면역능력이 온 전한 종양치료의 초기에 시행하는 것이 효과가 가장 좋 다고 한다.

암을 치료하는데 겪는 어려움 중의 하나는 전통적인 암 치료 방법으로는 암줄기세포(cancer stem cells)를 모두 제
거하기 어렵다는 점이다. 암줄기세포는 잠복상태를 유지 하여 전통적인 암치료제에 대하여 정상세포처럼 저항을 나타내고 살아남아서 암의 재발을 일으킨다. 암용해바이 러스는 잠복상태인 암줄기세포를 찾아가서 제거할 잠재 력을 가지고 있다. 최근 다수의 다른 종양에서 암용해바 이러스는 암줄기세포를 효과적으로 제거하였다(Chaurasiya et al., 2018). 생명연장이 아닌 암의 완치가 치료의 목적일 때 암용해바이러스를 활용할 수 있는 가능성이 엿보인다. 암용해바이러스에 적절한 여러 가지 기능적인 전이 유 전자(transgene)를 탑재하면 암용해바이러스에 다양한 항 종양기능을 부여할 수 있다. 다양한 종류의 암용해바이러 스 치료제 풀(pool)이 만들어지면 미래에는 종양의 종류 와 진행정도에 따라서 적합한 조합의 암용해바이러스를 선택할 수 있을 것이다.

암용해바이러스에는 극복해야할 장벽이 아직 많이 남 아있지만, 다양한 암용해바이러스 치료제의 개발이 진행 중인 것은 고무적인 사실이다. 암용해바이러스는 항암면 역의 활성도 면에서 다른 항암제에 비해 우수하여 치료 효과가 좋게 나올 것으로 기대된다. 암용해바이러스는 항 암 면역활성과 관련된 기능에서 1 세대 화학항암제, 2 세 대 표적항암제, 그리고 3세대 면역항암제인 면역관문억 제제, $\mathrm{T}$-세포 치료제 등과 비교 시 높은 활성도를 보였다 (Bommareddy et al., 2018). 치료 방법이 확립된 기존의 방 법과 같이 사용될 경우 치료효과가 더욱 높아질 것으로 예상된다. 잘 알려진 예로는 면역관문억제제와의 병용 투 여이다. 암용해바이러스 감염은 항종양면역반응을 자극 하여 면역관문억제제의 효과를 증진시킨다. 이에 따라 암 용해바이러스와 면역관문억제제를 병용 투여하는 임상시 험이 세계적으로 수행되고 있다(Sivanandam et al., 2019). 암용해바이러스 치료제의 개발이 진전되어서 종양치료에 유용한 선택이 되고, 암치료의 희망이 되어 주기를 기대 한다.

\section{ACKNOWLEDGEMENT}

None

\section{CONFLICT OF INTEREST}

The author certifies that I have no affiliations with or involvement in any organization or entity with any financial interest or non-financial interest in the subject matter or materials discussed in this manuscript. 


\section{REFERENCES}

Agarwalla PK, Aghi MK. Oncolytic herpes simplex virus engineering and preparation. Methods Mol Biol. 2012. 797: 1-19.

Andtbacka RHI, Ross M, Puzanov I, Milhem M, Collichio F, Delman KA, Amatruda T, Zager JS, Cranmer L, Hsueh E, Chen L, Shilkrut M, Kaufman HL. Patterns of clinical response with Talimogene laherparepvec (T-VEC) in patients with melanoma treated in the OPTiM phase III clinical trial. Annal Surg Oncol. 2016. 23: 4169-4177.

Bommareddy PK, Shettigar M, Kaufman HL. Integrating oncolytic viruses in combination cancer immunotherapy. Nat Rev Immunol. 2018. 18: 498-513.

Chaurasiya S, Chen NG, Warner SG. Oncolytic virotherapy versus cancer stem cells: a review of approaches and mechanisms. Cancers (Basel). 2018. 10: E124.1-19.

Cho MJ, Bae SE, Song YJ, Je MK, Jang JH, Son HS. Cancer research based on oncolytic virus. The Korean Journal of Public Health. 2013. 50: 46-58.

Davola ME, Mossman KL. Oncolytic viruses: how "lytic" must they be for therapeutic efficacy? Oncoimmunology. 2019. 8: e1581528.

Eissa IR, Bustos-Villalobos I, Ichinose T, Matsumura S, Naoe Y, Miyajima N, Morimoto D, Mukoyama N, Zhiwen W, Tanaka M, Hasegawa H, Sumigama S, Aleksic B, Kodera Y, Kasuya $\mathrm{H}$. The current status and future prospects of oncolytic viruses in clinical trials against melanoma, glioma, pancreatic, and breast cancers. cancers (Basel). 2018. 26; 10. pii: E356. doi: 10.3390/cancers10100356. Review.

Fukuhara H, Ino Y, Todo T. Oncolytic virus therapy: a new era of cancer treatment at dawn. Cancer Sci. 2016. 107: 1373-1379.

Garber K. China approves world's first oncolytic virus therapy for cancer treatment. J Natl Cancer Inst. 2006. 1; 98: 298-300.

Gong J, Sachdev E, Mita AC, Mita MM. Clinical development of reovirus for cancer therapy: an oncolytic virus with immunemediated antitumor activity. World J Methodol. 2016. 6: 25-42.

Greig SL. Talimogene laherparepvec: first global approval. Drugs. 2016. 1; 76: 147-154.

Guo ZS, Lu B, Guo Z, Giehl E, Feist M, Dai E, Liu W, Storkus WJ, He Y, Liu Z, Bartlett DL. Vaccinia virus-mediated cancer immunotherapy: cancer vaccines and oncolytics. J Immunother Cancer. 2019. 9; 7: 6. doi: 10.1186/s40425-018-0495-7.

Hoster HA, Zanes RP, Von Haam E, Studies in Hodgkin's syndrome: the association of viral hepatitis and Hodgkin's disease: a preliminary report. Cancer Res. 1949. 9: 473-480.

Howells A, Marelli G, Lemoine NR, Wang Y. Oncolytic virusesinteraction of virus and tumor cells in the battle to eliminate cancer. Front Oncol. 2017. 7: 1-15.

Hu JC, Coffin RS, Davis CJ, Graham NJ, Groves N, Guest PJ, Harrington KJ, James ND, Love CA, McNeish I, Medley LC, Michael A, Nutting CM, Pandha HS, Shorrock CA, Simpson J, Steiner J, Steven NM, Wright D, Coombes RC. A phase I study of OncoVEXGM-CSF, a second-generation oncolytic herpes simplex virus expressing granulocyte macrophage colony-stimulating factor. Clin Cancer Res. 2006. 12: 6737 $-6747$.

Kim YC. Developmental strategy of oncolytic virus therapy. Korean Drug Development Fund, Home page > Archieve > Research trend of new drug development. KDDF contribution. Oct. $30^{\text {th }}, 2017.1-9$.

Kohlhapp FJ, Kaufman HL. Molecular Pathways: Mechanism of Action for Talimogene laherparepvec, a new oncolytic virus immunotherapy. Clin Cancer Res. 2016. 22: 1048-1054.

Kwon SI. Anticancer immunotherapy, the game changer in the anticancer drugs, its development trend and prospect. J Korean High Voc Edu Asc. 2017. 18: 21-30.

Lawler SE, Speranza MC, Cho CF, Chiocca EA. Oncolytic viruses in cancer treatment: a review. JAMA Oncol. 2017. 3: 841-849.

Lundstrom K. New frontiers in oncolytic viruses: optimizing and selecting for virus strains with improved efficacy. Biologics. 2018. 9: 43-60.

Maroun J, Muñoz-Alía M, Ammayappan A, Schulze A, Peng KW, Russell S. Designing and building oncolytic viruses. Future Virol. 2017. 12: 193-213.

Martuza RL, Malick A, Markert JM, Ruffner KL, Coen DM. Experimental therapy of human glioma by means of a genetically engineered virus mutant. Science. 1991. 252: 854-856.

Naik S, Nace R, Federspiel MJ, Barber GN, Peng KW, Russell SJ. Curative one-shot systemic virotherapy in murine myeloma. Leukemia. 2012. 26: 1870-1878.

Parato KA, Breitbach CJ, Le Boeuf F, Wang J, Storbeck C, Ilkow C, Diallo JS, Falls T, Burns J, Garcia V, Kanji F, Evgin L, Hu K, Paradis F, Knowles S, Hwang TH, Vanderhyden BC, Auer R, Kirn DH, Bell JC. The oncolytic poxvirus JX-594 selectively replicates in and destroys cancer cells driven by genetic pathways commonly activated in cancers. Mol Ther. 2012. 20: $749-758$

Puzanov I, Milhem MM, Minor D, Hamid O, Li A, Chen L, 
Chastain M, Gorski KS, Anderson A, Chou J, Kaufman HL, Andtbacka RH. Talimogene laherparepvec in combination with Ipilimumab in previously untreated, unresectable stage IIIB-IV melanoma. J Clin Oncol. 2016. 34: 2619-2626.

Raja J, Ludwig JM, Gettinger SN, Schalper KA, Kim HS. Oncolytic virus immunotherapy: future prospects for oncology. J Immuno ther Cancer. 2018. 4; 6: 140. doi: 10.1186/s40425-018-0458-z.

Russell SJ, Federspiel MJ, Peng KW, Tong C, Dingli D, Morice WG, Lowe V, O'Connor MK, Kyle RA, Leung N, Buadi FK, Rajkumar SV, Gertz MA, Lacy MQ, Dispenzieri A. Remission of disseminated cancer after systemic oncolytic virotherapy. Mayo Clin Proc. 2014. 89: 926-933.

Sivanandam V, LaRocca CJ, Chen NG, Fong Y, Warner SG. Oncolytic viruses and immune checkpoint inhibition: the best of both worlds. Mol Ther Oncolytics. 2019. 13: 93-106.

Smith RR, Huebner RJ, Rowe WP, Schatten WE, Thomas LB. Studies on the use of viruses in the treatment of carcinoma of the cervix. Cancer. 1956. 9: 1211-1218.

Varghese S, Rabkin SD, Liu R, Nielsen PG, Ipe T, Martuza RL. Enhanced therapeutic efficacy of IL-12, but not GM-CSF, expressing oncolytic herpes simplex virus for transgenic mouse derived prostate cancers. Cancer Gene Ther. 2006. 13: 253 -265 .

Vollmer CM, Ribas A, Butterfield LH, Dissette VB, Andrews KJ, Eilber FC, Montejo LD, Chen AY, Hu B, Glaspy JA, McBride WH, Economou JS. p53 selective and nonselective replication of an E1B-deleted adenovirus in hepatocellular carcinoma. Cancer Res. 1999. 59: 4369-4374.

Woo HY, Hu J. Oncolytic viral therapy in hepatocellular cancer. The Korean Society of Liver. The 21st Autumn Academic Congress. www.kasl.org. 2015. 2: 35-41.

Yamada T, Hamano Y, Hasegawa N, Seo E, Fukuda K, Yokoyama KK, Hyodo I, Abei M. Oncolytic virotherapy and gene therapy strategies for hepatobiliary cancers. Curr Cancer Drug Targets. 2018. 18: 188-201.

https://doi.org/10.15616/BSL.2019.25.3.201

Cite this article as: Kwon SI. The Trend in the Development of Oncolytic Virus Therapy. Biomedical Science Letters. 2019. 25: 201-210. 